\title{
VELIKONOČNÍ TAJEMSTVÍ V LITURGICKÝCH TEXTECH ARABOFONNÍ KOPTSKÉ CÍRKVE
}

\author{
MLADA MIKULIC OVÁ
}

1 aje ajemství Kristova díla vykoupení jsou zřetelně vyslovena a připomínána v denních liturgiích koptské církve. Především je to eucharistická liturgie, ale také ranní a večerní kadidlová bohoslužba a liturgie kanonických hodinek, a to v koptském alexandrijském ritu. Egyptské liturgické texty byly původně řecké. Doba jejich překladu do koptštiny není známá, ale převládá názor, že se koptské překlady rozšírily z jižního Egypta zvláště po roztržce s Byzancí na chalcedonském koncilu (451), kdy odtržená alexandrijská církev začala používat koptštinu místo řečtiny. ${ }^{1}$ Egyptší melchité samozřejmě zůstali u řecké verze liturgie. Zbytky řečtiny jsou dodnes uchovány v některých replikách jáhna a lidu. Od desátého století nastoupila ve všech zemích bagdádského chalífátu arabština jako oficiální jazyk, prosadila se postupně $\mathrm{v}$ běžném životě obyvatel arabizovaných zemí a přešla časem i do církevních textů a liturgie. Ortodoxní církev traduje starobylé liturgické texty beze změny, ač používá jako liturgický jazyk arabštinu, do různé míry promíšenou řecko-koptskými útržky. Koptská katolická církev tradiční liturgii svatého Basila zkrátila a zjednodušila.

V následujícím přehledu si povšimneme velikonočních pasáží dvou liturgických knih, používaných v současné koptské církvi, a jejich specifického idiomu, který meditativním způsobem s úctou opakuje a z různých úhlů prohlíží tajemství spásy v Kristu.

1 Výklad koptské liturgie svatého Basila: BARSŪM, Louis, OFM. Dhabīhat al-quddās al-ilāhì wa-šarh al-quddās al-bāsīlì. Al-Qāhira: al-Ma had al-iklīrīkī al-fransiskānī al-qibtṭī bil-Gīza, 1981, s. 62. 


\section{Liturgické knihy: chulágí a agpíja}

\subsection{Chulágí: euchologion}

Základní liturgickou knihou je euchologion. Řecký název přešel do koptštiny a posléze arabštiny v podobě chulágí (chūlā̆ğ̀). ${ }^{2}$ Obsahuje především tři kanonické anafory (quddās): svatého Basila, svatého Řehoře a svatého Marka. Tuto trojici stanovil pro koptskou ortodoxní církev patriarcha Gabriel ibn Turajk (1131-1145) s vyloučením ostatních liturgií.

Anafora sv. Basila, nejužívanější ze všech tří, je v koptské verzi kratší než její syrské, arménské a byzantské varianty a představuje jiný typ. Je doložena v rukopisech od sedmého století jak v koptském sa ídském znění, tak v pozdějším buhajrském. První publikace se dočkala v Římě roku 1636, ačkoli dnes se přetiskuje pozdější a důkladnější zpracování rukopisů od Klaudia Labíba. ${ }^{3}$ První novodobé euchologion vydal hegúmen Abd al-Masíh Salíb al-Mas údí. Podle něj vycházejí reprinty kláštera Muharraq z let 1956 a 1997 a také četné kopto-arabské verze z káhirského koptského nakladatelství al-Mahabba nebo arabsko-anglické překlady. Anafora sv. Řehoře Theologa představuje syrskou tradici v koptské církvi. Používá se o svátcích Páně. Je christocentrická a pochází z šestého století, kdy se do kláštera ve Vádí al-Nátrún (Skétis) uchýlili syrští monofyzitští mniši. Nejstarší rukopisné zlomky však pocházejí až z desátého století ze sa ídské metropole Ašmúnajn. Moderní Labíbova verze je opět přetiskována podle euchologia z roku 1908. Postní anafora sv. Marka, častěji nazývaná anaforou svatého Cyrila Alexandrijského, se výrazně liší od syrobyzantských liturgií. Řecké a koptské rukopisy se datují od šestého století.

Všechny tři liturgie jsou obsaženy v moderních vydáních misálu s názvem Posvátné euchologion (al-chulāğı̀ al-muqaddas). Euchologia vydává koptské nakladatelství al-Mahabba ve dvojjazyčném provedení, bud' kopto-arabském, nebo arabsko-anglickém. ${ }^{4}$ Citace v následujícím

2 K přepisu arabských slov v kurzívě a v poznámkách: q označuje postvelární k (nikoli kv), ğ je značka pro dž (v egyptské výslovnosti g), ‘označuje hrtanovou souhlásku,' je závěrová souhláska, tečky pod souhláskou znamenají emfatickou výslovnost, u h jode o dyšnou výslovnost. Délky jsou zaznamenány vodorovnou čárkou. V hlavním textu je výslovnost zjednodušená do české podoby.

3 Historie textů anafor je pojednána v GABRA, Gawdat. Historical Dictionary of the Coptic Church. Cairo: American University Press, 2008, s. 27-29.

4 Arabsko-anglické vydání: The Coptic Liturgies / al-Quddāsāt al-qibtīja: the Holy Kholagy / al-Chūlāğ̀̃ al-muqaddas. Cairo: Mahabba Bookshop, 2004. Kopto-arabská 
pojednání jsou z arabsko-anglické verze z roku 2004, se zkráceným názvem Chulágí.

Mimo uvedené anafory obsahuje euchologion také další liturgické texty: ranní a večerní kadidlovou liturgii ( $r a f^{\prime}$ buchūr), modlitby při lámání svátostného Chleba (qism), sváteční a př́ležitostné hymny (alḥ̄n) a zpívané odpovědi ke čtení ze Skutků (muradd al-ibraksīs).

V lidovém, kapesním vydání jsou do euchologia zařazeny také děkovné písně při přijímání (tarānīm) a modlitby (șalāwāt) k přijímání a pro denní doby.

\subsection{Agpíja}

Koptské slovo agip znamená hodina a stejnojmenná liturgická kniha obsahuje především kanonické, původně mnišské modlitby pro jednotlivé denní a noční doby. Je jich celkem sedm (sab'șalāwāt), podle koptského znění slov žalmu „sedmkrát denně chválím tvé spravedlivé soudy“.5 Každá hodinka sestává z řady žalmů - většinou je jich dvanáct, po nichž následuje čtení z evangelia a několik modliteb Otců na závěr. ${ }^{6}$ První ranní hodinka ( $\left.b \bar{a} k i r\right)$ se koná při východu slunce a je tematizována připomínkou vzkříšení Páně. Dopolední hodinka, zvaná Třetí (al-thālitha), připadá přibližně na devátou hodinu. Jejím námětem je připomínka sestoupení Ducha svatého na apoštoly. Polední modlitba je šestá hodina od východu slunce (al-sādisa) s připomínkou ukřižování Páně a naplnění spásy. Odpolední hodinka, devátá (al-tā$\left.s i^{\prime} a\right)$, se koná kolem třetí hodiny našeho času ve znamení smrti Páně na kříži a příslibu ráje pro lotra po pravici. Hodinka při západu slunce (al-ghurūb) připadá asi na pátou hodinu a čas sejmutí těla Pána Ježíše z křiže. Asi o hodinu později je chvíle na modlitbu před spaním (șalāt al-naum), což je kanonicky dvanáctá hodina s připomínkou uložení těla Kristova do hrobu a vlastní memento mori. Sedmá hodinka sestává ze tří nočních modliteb (salāt muntașif al-lajl) představujících Ježíšovo bdění v Getsemanské zahradě a jeho trojí modlitbu. První modlitba je rozjímání o bdělosti podle žalmů a podobenství o deseti družičkách

verze: Al-Chūlā̆ğ̀ al-muqaddas. Al-Qāhira: Maktabat al-Mạ̣abba, 2000. Koptský text je psán arabským písmem.

5 Žalm 118,164 podle koptského řazení shodného se Septuagintou. Podle hebrejského řazení Žalm 119.

6 Ačkoli forma agpíje do značné míry odpovídá latinské Liturgii horarum, není zcela totožná, a proto záměrně neuvádíme latinizující názvosloví Prime, Terce, Sext, None, Vespers, Compline, Vigils, které mají moderní koptské publikace. 
z Matoušova evangelia (25,1-13). Druhé bdění otvírá téma pokání podle př́běhu o farizeovi a kající hříšnici četbou z Lukášova evangelia (7,35-50). Třetí bdění představuje očekávání Kristova druhého příchodu podle jeho vlastních slov (Lukášovo evangelium 12,32-64). Agpíja ještě nabízí dlouhou mnišskou noční modlitbu závoje (șalāt al-sitār) sestávající z jednatřiceti žalmů a rozjímání nad zázrakem utišení bouře. Jsou zde také kněžské prosby za zbavení od zla a hříchu (taḥlīl al-kahina) ${ }^{7}$ po půlnoční hodince a několik dalších modliteb: před zpovědí, po zpovědi, před přijímáním, po přijímání, před jídlem, před začátkem práce, a také obecná prosebná modlitba (țalaba). Agpíja je vydávána i pro laiky, a to rovněž v paralelní arabsko-anglické podobě s koptskými vsuvkami. ${ }^{8}$

Koptská církev používá ještě další liturgické knihy, jako lekcionář katamarus (qatāmārus, kat'imiros), hymnáře difnar (antifonarion) a psalmodia a také sinaksar (synaxarion) - lekcionář životopisů světců. Ty však nejsou předmětem tohoto pojednání.

\section{Velikonoční tajemství v kanonických hodinkách}

V agpíji se velikonoční události připomínají obzvláště v polední a odpolední hodince, které jsou tematizovány skutečností ukřižování Páně. Ranní hodinka však obsahuje dva texty, známé i z jiných liturgií: trisagion, které je také součástí anafory, a vyznání víry z křestní liturgie.

\subsection{Trisagion}

Svatý Bože, svatý silný, svatý nesmrtelný, který ses zrodil z Panny, smiluj se nad námi. Svatý Bože, svatý silný, svatý nesmrtelný, který jsi byl za nás ukřižován, smiluj se nad námi. Svatý Bože, svatý silný, svatý nesmrtelný, který jsi vstal z mrtvých a vstoupil na nebesa, smiluj se nad námi. (Agpíja, s. 88-89)

Tento starokřestanský zpěv se zpravidla recituje řecky v koptské výslovnosti: Agios o Theos agios iširos agios athanatos o ek partheno gennethis eleison imas. Agios o Theos agios iširos agios athanatos o stavrothis diimas, eleison imas. Agios o Theos agios iširos agios athanatos

7 V anglickém překladu je Prayer of Absolution, modlitba rozhřešení. Latinská terminologie však plně nepostihuje obsah koptského textu. Taḥlīl převážně obsahuje prosby o ochranu před hř́chem a rozmanitými podobami zla jak pro sebe tak přímluvně pro druhé.

8 The Agpeya / al-Agbīja. Al-Qāhira: Maktabat al-Maḥabba, 2003. 
o anastas ek ton nekron ke anelthon is tus uranus, eleison imas. Agpíja však uvádí také arabskou verzi.

Trisagion je zařazeno po dvanácti žalmech a prologu k evangeliu svatého Jana jako čtvrtá modlitba: po chvále Krista - Světla světa, chvále Matky Boží - Matky Světla a po chvalozpěvu Sláva na výsostech Bohu.

\subsection{Vyznání víry (qānūn al-īmān)}

... on pro nás lidi a pro naši spásu sestoupil z nebe, vtèlil se z Ducha svatého a Panny Marie a stal se človékem. Byl za nás ukřižován za Pontia Piláta, trpèl a byl pohŕben. Tŕetího dne vstal z mrtvých podle Písma a vstoupil na nebesa a usedl po pravici svého Otce, odkud príide ve slávé soudit živé i mrtvé a jeho království bude bez konce... (Agpíja, s. 94-95)

Vyznání víry následuje po Trisagion a pozdravení Bohorodičky (al-salāmu laki). Po něm nastupuje řada prosebných modliteb: Kyrie eleison, prosba k Pánu zástupů (Svatý, svatý, svatý Pán), dvojí prosba o ochranu (tahlīll) a závěr.

\subsection{Vyznání smrti Pánè z polední hodinky}

Ježiši Kriste, náš Bože, který jsi byl prribit na kř́ž v šesté hodině a dřevem křize jsi zahubil hřich, svou smrtí jsi vzkř́sil mrtvého, jehož jsi stvořil vlastnima rukama a který zemřel $v$ hríchu. Zahub naše bolesti svým uzdravujicim a životadárným utrpenim a hřeby, jimiž jsi byl přibit. ... Dokonal jsi spásu na zemi, Kriste, náš Bože, když jsi rozpjal své svaté ruce na kř̉z.... Kriste, náš Bože, který ses ze své vlastni vưle nechal pozvednout na kř́ż, abys zachránil z pout neprítele ty, které jsi stvořil... (Agpíja, s. 176, 179 a 180)

Texty polední hodinky se vztahují ke smrti Páně na kříži a k vykoupení člověka. Po dvanácti žalmech o utrpení a záchraně následuje evangelium blahoslavenství. Závěrečné modlitby Otců (qịta) ukazují linii vykoupení od stvoření prvního člověka a jeho smrti jako následku hříchu ke spásnému utrpení Krista, které dobrovolně podstoupil k vysvobození člověka z pout smrti. Tuto linii Boží spásy souhrnně vyjadřuje chvála Panny Marie:

Rodicko Boži, Panno, chválime tě, nebot'skrze křiž tvého Syna padlo peklo a smrt byla přemožena. Byli jsme mrtví, ale jsme vzkř́išeni a hodni véčného života. Ziskali jsme blaženost prvního ráje... (Agpíja, s. 182)

$\mathrm{V}$ závěrečném tahlílu je vyjádřena vděčnost Otci za zrušení viny skrze smrt Syna. 
Dékujeme ti, náš Králi, všemohoucí Otče našeho Pána, Boha a Spasitele Ježíše Krista, a oslavujeme tè, že jsi premènil čas utrpeni svého jednorozeného Syna v čas útéchy a modlitby. ... Přijmi naši prosbu a zruš zápis o našich provinènich, který stoji proti nám, jako jsi jej roztrhl $v$ tuto hodinu křǐem svého jednorozeného Syna Ježiše Krista, našeho Pána a Spasitele našich duší... (Agpíja, s. 183)

\subsection{Spása lotra po pravici z odpolední hodinky}

Který jsi v deváté hodině zakusil smrt v tẻle za nás hř́šniky, znič naše tèlesné touhy...

Který jsi odevzdal ducha do rukou Otce, když jsi v deváté hodinè visel na křiži, který jsi uvedl do ráje lotra, který byl spolu s tebou ukrižován, nezavrhuj mè, Dobrotivý...

Který ses kvưli nám narodil z Panny, strpèl ukřižováni, a tak jsi, Dobrotivý, zrušil smrt svou smrti a svým vzkřišsením ukázal vzkř́išení, neodvracej se, Bože, od tèch, které jsi stvořil svýma rukama... (Agpíja, s. 212-215)

Odpolední hodinka je celá tematizovaná př́během o lotru po pravici, od žalmů o Boží záchraně k evangeliu o nasycení tisíců. Modlitby mají litanickou formu a podobně jako lotrova prosba jsou adresovány Kristu - Dobrotivému (al-șālih): v úvodním oslovení se připomíná Kristův spásný čin, prosba reflektuje formulace žalmů - nezavrhuj, neodvracej se. V druhé části je refrénem žádost lotra po pravici: Pamatuj na mne, Pane, až přijdeš do svého království. Jednotlivé části modlitby podle Otců (qịta') jsou odděleny koptskou doxologií (doxa Patri ke Ijo...).

Když lotr uvidél Pána života viset na kř́ži, rekl: Kdyby ten, který je s námi ukřižován, nebyl vtèlený Bůh, slunce by neskrylo svou zár̆ a zemè by se nezachvèla. Ale ty, V̌́emohouci, který jsi strpèl to všechno, pamatuj na mne, Pane, až prijdeš do svého království...

Který jsi prijal vyznáni lotra na křǐzi, prijimi nás k sobě, Dobrotivý, nás, kdo si zasluhujeme smrt za své hřchy... Pamatuj na nás, Pane, až prijideš do svého království. (Agpíja, s. 216-218)

Poslední v řadě modliteb je připomínka pláče Matky Boží:

Když Matka uvidèla Beránka a Pastýre, Spasitele svéta viset na křǐzi, rekla s pláčem: Svét se raduje, že se mu dostalo spásy, mé srdce však hoři, když vidim tvé ukřižování, jež trpiš kvůli nám všem, můj Synu a můj Bože. (Agpíja, s. 219-220)

Po inkantacích Kyrie eleison a Svatý, svatý následuje závěrečný tahlíl s identifikací: my jako lotr, my jako sedící v temnotě. 
Přijmi nás k sobě, náš Pane, Ježíši Kriste, jako jsi prrijal lotra po tvé pravici, když jsi visel na kř̌ži. Osvit' nás svým svétlem, jako jsi zazárril nad tèmi, kteř́ byli $v$ temnoté pekla, a uved' nás opét do ráje radosti... (Agpíja, s. 222)

\section{Připomínka Kristovy oběti v kadidlové liturgii ( $r a f^{\prime}$ buchūr)}

Kadidlová liturgie, ranní i večerní, je uvedena v euchologiu. Obětí kadidla připomíná nekrvavým způsobem Kristovu krvavou obět na kř́ǐzi.

\subsection{Modlitba knèze z večerní liturgie}

... Kéž naše modlitby stoupaji před tebe jako kadidlo, naše pozvednuté ruce jako večerni obèt' (dhabīha). Nebot' ty jsi pravá večerni obèt, který jsi pro naše hřichy sám vystoupil (aș 'adta dhātaka) na vznešený kríž podle vůle svého Otce... (Chulágí, s. 20-21)

Prosbu za přijetí vonné oběti pronáší kněz poté, co vložil do kadidelnice pět zrn kadidla. Následují verše s cymbálky: chvála Nejsvětější Trojice a Matky Boží. Pak bohoslužba pokračuje přímluvami za zemřelé a za shromáždění věřících, po ní se čte evangelium, následují přímluvy za pokoj, za církev a zemi a bohoslužba končí trojím tahlílem a požehnáním.

\subsection{Z tahlílu}

Druhý tahlíl kadidlové liturgie připomíná Kristovo spásné vtělení:

Pane, který jsi sklonil nebesa, ty sám jsi sestoupil a stal ses človékem ke spáse (chalāṣ) lidského rodu... (Chulágí, s. 64)

V třetím tahlílu zaznívá prosba o odpuštění hříchů, které umožnila Kristova obět:

Pane, Ježiši Kriste, jednorozený Synu a Slovo Otce, který jsi zlomil pouta našich hřichů svým spásonosným, životadárným utrpením... daruj nám své milosrdenství a uvolni pouta našich hríchů... (Chulágí, s. 68 a 70$)$

Jako na mnoha jiných místech i zde vyjádřeno propojení mezi vtělením Božího Syna a velikonočními událostmi spásy. 


\section{Velikonoční tajemství v liturgii svatého Basila}

Liturgie svatého Basila se slaví jak v koptské ortodoxní církvi, tak v unifikované katolické, avšak liturgické texty nejsou úplně totožné. První je obsažen ve zmíněném euchologiu, ${ }^{9}$ druhý, upravený, vydal koptský katolický patriarchát v Káhiře roku $1990 .{ }^{10}$ Ortodoxní anafora obsahuje celou liturgii v její starobylé formě, katolická je zkrácená a odpovídá soudobým liturgickým zvyklostem katolické církve. Je zpívaná, avšak pouze arabsky, její jazyk je jednodušší a civilnější, oproštěný od mnohých starobylých vyjádření, biblicismů, honorifik a repetic.

\subsection{Modlitba při obètování (șalāt al-tuqaddima)}

Pane Ježiši Kriste, soupodstatné Slovo Otce, který jsi bez poskvrny (al-šarīk al-dhātī wa kalimat al-Ab ghair al-danas), jedné podstaty $s$ ním a s Duchem svatým (al-musāwì lahu ma' al-Rūh al-qudus), ty jsi živý chléb, který sestoupil z nebe. Učinil ses Beránkem bez poskvrny obètovaným za život svéta... Ukaž svou tvár nad tímto chlebem a nad tímto kalichem, který jsme položili na tvưj kněžský stůl. Požehnej je, posvét' je, očist' je a promén je, aby se tento chléb stal tvým svatým tẻlem a tato smès, která je $v$ kalichu, aby se stala tvou prevzácnou krví a aby nám tak oboji prineslo povzneseni (irtiqā'), uzdraveni (šifā') a spásu (chalāṣ) pro duši, tèlo i ducha. (Chulágí, s. 97-99)

Tuto tichou modlitbu pronáší kněz nad obětními dary, které se připravují na začátku liturgie po kanonických hodinkách včetně ranní kadidlové. K obětování patří Beránkův průvod, žehnání Beránka, pozdravení pokoje, po němž přichází uvedená obětní modlitba. Následuje prosba o milost pokání a za zbavení vin (tahlīl), hymnus o kadidelnici, př́mluvy a čtení z epištol, Skutků, synaxaria a evangelia. ${ }^{11}$ Před prvním čtením kněz v koptštině pronáší krátkou chválu Spasitele:

9 The Holy Kholagy / al-Chulāğḡi al-muqaddas, s. 82-234. Al-Chulāğ̄̄ al-muqaddas, s. 49-144. Text i s výkladem je dostupný v angličtině online ve formátu pdf. SLEMAN, Abraam D. St. Basil Liturgy Reference Book, The Full Text, Step by Step Explanations, Commentaries. http://www.copticchurch.net/topics/liturgy/index.html. Staženo 14. 8. 2011.

10 Ti-anafora ente pi-agios megalou Basilios / Quddās al-qiddīs Bāsīlīūs al-kabīr. Al-Qāhira: Bațrirkīja al-aqbāt al-kāthūlīk, 1990.

11 První čtení - Apostolus - je z některého listu svatého Pavla, druhé - Katholikon - je z některé obecné epištoly. Třetí čtení se nazývá Praxis (Abraxīs). Čtvrté čtení ze synaxaria je zvykem v koptské ortodoxní církvi. Poslední čtení je z evangelia. Všechny úryvky se čtou koptsky a arabsky. 
Klanime se ti, Kriste, s tvým dobrým Otcem a Duchem svatým, nebot' jsi prišel a zachránil nás. (Chulágí, s. 114) ${ }^{12}$

Podobným koptským vyznáním také odpovídá lid na třetí čtení, které je ze Skutků apoštolů (Praxis, abraksiss):

Požehnaný jsi vskutku se svým dobrým Otcem a Duchem svatým, nebot' jsi prišel a zachránil nás. (Chulágí, s. 125)

\subsection{Trisagion}

Trisagion (al-taqdīsāt al-thalātha) zpívají všichni v koptštině před čtením evangelia. Vyznává vtělení, ukřižování a zmrtvýchvstání Krista.V ortodoxní liturgii je text opět řecký s koptskou výslovností, stejný jako $\mathrm{v}$ ranní hodince, s možným překladem do arabštiny. Je ukončen trojiční doxologií.

Svatý Bože, svatý silný, svatý nesmrtelný, který ses zrodil z Panny, smiluj se nad námi.

Svatý Bože, svatý silný, svatý nesmrtelný, který jsi byl za nás ukřižován, smiluj se nad námi. Svatý Bože, svatý silný, svatý nesmrtelný, který jsi vstal z mrtvých a vstoupil na nebesa, smiluj se nad námi. (Chulágí, s. 127-129; Anafora, s. 13)

Stejně jako v ranní liturgii hodinek je v řadě modliteb po evangeliu obsaženo také vyznání víry s jeho kristologickými články o vtělení, utrpení, smrti a vzkříšení. Text vyznání se recituje, jen poslední verš o vzkříšení mrtvých a životě budoucího věku se zpívá. ${ }^{13}$

\subsection{Z modlitby o nápravě podle svatého Jana}

Modlitba o nápravě (ṣalāt al-ṣalh, muṣāliha) je vyznáním Božího díla nápravy skrze Kristovu obět na usmíření hříchů. Následuje po vyznání víry a před „Vzhůru srdce“. Kněz se ji modlí nahlas arabsky. Z několika možných textů může zvolit musálihu svatého Jana, v níž je následující vyznání o duchovní eucharistické oběti.

... ustanovil jsi pro nás dílo (tadbìr) svého jednorozeného Syna a skryté tajemstvi této obèti (dhabīha), při niž neteče krev zákona, ani

12 Ten wu-ošt emmok o pi-Christos nem pek Jot en-aghathos nem pi-Pnevma ethwab dže ak-sóti emmon. Tuto krátkou modlitbu pronáší také v úvodní části kadidlové liturgie.

13 Formulační rozdíl je ve výrazu pro vtělení: ortodoxní text má „vtělil se z Ducha svatého a z Panny Marie a stal se člověkem“ (tağassada min al-Rüḥ al-qudus wa Marjam al-'adhra'), zatímco v katolickém je „skrze Ducha svatého (bil Rūh al-qudus) přijal tělo z Marie Panny a stal se člověkem“. Katolické vyznání také obsahuje filioque (almunbathiq min al-ab wa-l ibn). 
nejde o ospravedlnèni tèla, ale Beránek je duchovní (rūhī) a nůž je myšlený ('aqlīja), nikoli hmotný (ghajr ğismīja). To je ta obèt', kterou ti préedkládáme. (Chulágí, s. 190)

V katolické liturgii svatého Basila je tajemství díla spásy shrnuto takto:

Velký, véčný Bože, ty jsi stvořil človèka bez viny a porušení. Přchodem našeho Spasitele Ježiśse Krista, tvého milovaného Syna, jsi zrušil smrt, která vstoupila do světa skrze Satana, a naplnil jsi svět nebeským pokojem... (Anafora, s. 19)

Po této modlitbě usmírení následuje pozdravení pokoje mezi věřícími a končí část zvaná liturgie katechumenů (quddās al-mau'ūẓīn).

\subsection{Eucharistická modlitba: cesta spásy}

V obou formách anafory svatého Basila začíná eucharistická modlitba dialogem mezi knězem a věřícími typizovaným vybídkou „vzhůru srdce“. Po andělském trisagion začíná eucharistická modlitba, která shrnuje cestu spásy. Lid stvrzuje jednotlivé Boží skutky vyznáním víry: amen, vskutku, věříme. Následující text je z ortodoxní liturgie, významnější odchylky v katolické anafoře jsou uvedeny v poznámkách.

Kněz: Agios, agios, agios, svatý, svatý, svatý jsi vskutku, Pane, náš Bože, který jsi nás stvoŕil a umistil do ráje blaženosti. Kdyžjsme neuposlechli tvého př́kazu kvi̊li svodu odvékého hada, byli jsme zbaveni véčného života a vyhnáni z ráje blaženosti. Ale ty jsi nás neopustil navždy, ale ustavičnè jsi nás nabádal skrze své svaté proroky a v posledním čase ses nám zjevil, nám, sedicím v temnotě a stínu smrti, ve svém jednorozeném Synu, našem Pánu a Spasiteli Ježiši Kristu, (zrozeném) z Ducha svatého a Panny Marie. ${ }^{14}$

Lid: Amen. Vskutku, amen.

Kněz: Vtélil se a stal se človékem a ukázal nám cestu spásy. Skrze vodu a Ducha nám daroval narozeni, které je shüry..$^{15}$ Ućinil si $z$ nás shromáždèní (ša ban muğtama an) ${ }^{16}$ a očistil nás svým svatým Duchem. Miloval své, kteř́ jsou ve svétě a za naši spásu vydal sám sebe smrti, která nad námi vládla a jíž jsme byli podrobeni za své hřichy. Skrze kř̌ž sestoupil do pekel (马̆ahìm). ${ }^{17}$

14 ... který se vtělil skrze Ducha svatého z Panny Marie (Anafora, s. 22).

15 ... daroval nám nové narození z vody a z Ducha (Anafora, s. 22).

16 ... učinil si z nás jediný lid (ša ban wạhịidan) (Anafora, s. 22).

17 Miloval nás lidi, za nás vydal sám sebe na smrt a daroval nám svobodu skrze kříž (Anafora, s. 23). Zkráceno o věty o podrobení hříchu a smrti a sestupu Krista do pekel. Ğahīm je z řecko-hebrejského gehenna, místo věčného ohně. 
Lid: Vskutku věříme.

Kněz: Třetího dne vstal z mrtvých, vstoupil na nebesa a usedl po tvé pravici, Otče. Ustanovil den zúčtováni (jauman lil-mă̆āza), v nèmž se znovu objeví,18 aby soudil svét spravedlivě a dal každému podle jeho skutkü.

Lid: Podle tvého milosrdenství, Pane, ne podle našich hříchů. (Chulágí, s. 167-170)

Po úvodu o lidské vině a zbavení věčného života modlitba vyznává články víry o cestě spásy - mimořádné Boží záchraně: vtělení Božího Syna, vydání k trestu smrti pro lidský hřích, ukřižování, smrt a sestup do pekel, zmrtvýchvstání, vystoupení do Boží slávy a budoucí soud.

\subsection{Slova proméňování}

Následuje připomínka a zpř́tomnění poslední večeře Páně s ustanovením svátosti eucharistie, jejíž text se arabsky nazývá „podstatná slova“ (al-kalām al-ğauharī). Lid stvrzuje každý jednotlivý výrok vyslovením víry. V závěru je opět vysloveno vyznání o Kristově velikonočním díle spásy.

Kněz: Ustanovil pro nás toto velké tajemstvi: Rozhodnut, že se sám vydá na smrt za život svéta,

Lid: Věríme.

Kněz: vzal do svých svatých, neposkvrnèných, požehnaných a životadárných rukou chléb, ${ }^{19}$

Lid: Věříme, že to je skutečnost, amen.

Kněz: pohlédl vzhưru $k$ nebi, $k$ tobě, Bože, který jsi jeho Otec a Pán všech, vzdal diky,

Lid: Amen.

Kněz: požehnal jej,

Lid: Amen.

Kněz: posvétil,

Lid: Amen, věříme, vyznáváme a vzdáváme chválu.

Kněz: rozlámal jej a dával svým svatým učedníkům a apoštolům se slovy: Vezmète, jezte z toho všichni; toto je moje Télo, které se láme

18 Ustanovil den, v němž se znovu objeví (Anafora, s. 23). Vynechána zmínka o dni zúčtování.

19 Když přišla hodina, kdy se měl odevzdat smrti za život světa, ustanovil pro nás tajemství nejsvětější oběti (al-qurbān al-muqaddas). Vzal do svých svatých, neposkvrněných, požehnaných a životadárných rukou chléb (Anafora, s. 23-24). 
(juqassamu) pro vás a pro mnohé, dáno na odpuštèní hríchů. ${ }^{20}$ To čiňte na mou památku.

Lid: To je skutečnost. Amen.

Kněz: Po večeři smisil v kalichu štávu z hroznů a vodu, vzdal diky, Lid: Amen.

Kněz: požehnal jej,

Lid: Amen,

Kněz: posvětil,

Lid: Amen. I toto věříme, vyznáváme a vzdáváme chválu.

Kněz: okusil a také dal svým svatým učednikům a apoštolům se slovy: Vezmète a pijte $z$ toho všichni; to je moje Krev nové smlouvy, která se prolévá za vás a za mnohé na odpušténí hřichư. To čiňte na mou památku.

Lid: Také toto je skutečnost, amen.

\subsection{Připomínka obèti}

Kněz: Kdykoli jite z tohoto chleba a pijete z tohoto kalicha, zvěstujete mou smrt, vyznáváte mé vzkríšeni a pamatujete na mne, dokud neprijidu.

Lid: Amen, amen, amen. Tvou smrt, Pane, zvěstujeme, vyznáváme tvé svaté vzkříšení a nanebevstoupení. Klaníme se ti, chválíme tě, Pane a utíkáme se k tobě, náš Bože.

Kněz: Proto si také připomínáme jeho svaté utrpení, jeho vzkřišeni z mrtvých, jeho nanebevstoupeni, jeho usednuti po tvé pravici, Otče, a jeho druhý príchod, který bude z nebe, hrozný a slavný:21 Obètujeme ti dary, které jsou tvé, za všechno, co je (kull ḥăl), kvưli všemu a ve všem...22 (Chulágí, s. 171-179)

Poté, co kněz i lid nad Chlebem a Kalichem vyznali aktuální obět Kristova těla a krve, kněz $\mathrm{v}$ tiché modlitbě připomíná její účinnost k odpuštění hříchů přítomných věřících:

Náš Pán, Bůh a Spasitel Ježíš Kristus je dán na odpuštèni hř́chů a véčný život téch, kdo jej budou poživat (li-man jatanāwalu minhu). (Chulágí, s. 181-182)

20 ... které se vydává (jubdhalu) za vás a za všechny lidi na odpuštění hříchů (Anafora, s. 24).

21 ... jeho druhý př́íchod ve veliké slávě (Anafora, s. 26).

22 Obětujeme ti tuto životadárnou obět s díky za všechno (Anafora, s. 26). 
Následují přímluvy za pokoj, za církev, za potřeby obce, za zemřelé, modlitba při lámání Chleba (qisma), která je proměnlivá a její velikonoční formulace jsou uvedeny níže v šestém oddíle.

\subsection{Z modlitby odevzdání}

Po společné modlitbě Páně se kněz tiše modlí modlitbu odevzdání (șalāt al-chudū ), v níž jsou znovu shrnuta tajemství Kristova spásného díla.

Milost a dobrodini tvého jednorozeného Syna, našeho Pána, Ježiše Krista jsou naplnèna. Vyznali jsme jeho spásné utrpení, oznámili jsme jeho smrt, uvérili jsme v jeho vzkřrišení. Tajemství je dokonáno... (Chulágí, s. 210)

Po chudú kněz ještě pronáší další tichou prosbu o odpuštění hříchů svých i shromáždění, zakončenou zvoláním „Svaté svatým“ a po pozdravení pokoje následuje vyznání přítomnosti Kristova Těla (i'tirāf).

\subsection{Vyznání o Kristovu Tèlu}

Amen, amen, amen. Vérim, ${ }^{23}$ vérím, vérím a vyznávám do posledniho dechu, že toto je životadárné Tèlo, které tvůj jednorozený Syn, nás Pán, Bủh a Spasitel Ježiš Kristus prijal z naši Paní, Paní nás všech, svaté Bohorodičky Marie. Spojil je se svým božstvím (ma lāhūtihi) bez smišeni (bi-ghajr ichtilāt), bez sloučeni (lā imtizā̆ğ) a beze zmèny (lā taghajjir). Učinil náležité vyznáni pred Pontským Pilátem. ${ }^{24}$ Vydal je (aslamahu) za nás na svatém dřevu kř́že, ze své vlastní vưle a za nás za všechny. Vskutku vyznávám, že jeho božstvi ani na chvíli, ani na okamžik neopustilo jeho lidství. ${ }^{25}$ Dává se za nás, za spásu a odpuštèní hř́chů a véčný život těch, kdo je poživaji. Vérím, véř́m, věř́m, že je to skutečnost. Amen. (Chulágí, s. 223-224)

Vyznání pronáší kněz před přijímáním a nad posvátnými zpo̊sobami zdůrazňuje aktuálnost událostí spásy v prrítomném eucharistickém Těle Kristově: spojení božství s lidstvím v Kristu, jeho dobrovolné odevzdání k oběti na kříži za naši spásu, odpuštění hříchů a věčný život pro ty, kdo toto tajemné Tělo přijímají.

23 V katolické liturgii kněz mluví v plurálu i za ostatní: věříme (Anafora, s. 40).

24 V katolické liturgii je tato věta vynechána.

25 ... se ani na okamžik neoddělilo od jeho lidství. 


\section{Zmínky o vtělení a vykoupení v liturgii svatého Řehoře Theologa}

Z anafory svatého Řehoře uvedeme ty části, kde jsou velikonoční témata vyslovena odlišným, jedinečným způsobem.

\subsection{Modlitba o usmírení hř́chů}

Po vyznání víry následuje stejně jako v liturgii svatého Basila modlitba o usmíření hříchů (șalha), v níž je zde vedena linie mezi vtělením, vykoupením a zdokonalením lidství skrze Krista.

Ty sám, který jsi beze zmény (bi-ghajr istihāla), ses vtèlil, stal ses človékem a pripodobnil ses nám ve všem kromě hrúchu. Stal ses naším prostřednikem u Otce (wasịt ladaj al-ab) a strhl jsi zed' (hăğgiz), která byla mezi námi, zrušil jsi staré nepŕátelství, smiŕil jsi pozemštany s nebeštany a učinil jsi $z$ obou jedno. Přvedl jsi $k$ dokonalosti řád vtèleni (tadbìr

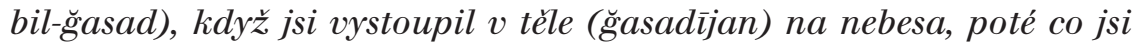
všechno naplnil svým božstvím. (Chulágí, s. 240-241)

\subsection{Ze salhy patriarchy Severa}

... ve svém nepopsatelném sestoupení (tanzill) a ve své lásce $k$ lidstvu jsi nesežehnul podvodného zrádce, když se k tobě približil, ale pozdravil jsi jej prátelským políbením, a tak jsi jej priviedl k lítosti (al-tūba), takže pochopil svou bezostyšnost... (Chulágí, s. 247-248)

V této části alternativní salhy zaznívá narážka na Jidášovu zradu v Getsemanské zahradě a jeho pokání, obrazném pro život křestana.

\subsection{Z eucharistické modlitby}

Kněz: Ty, můj Pane, jsi zménil můj trest ve spásu... Strpèl jsi bezpráví, jež spáchali nespravedliví, nabidl jsi záda bičování, nastavil jsi tvár polićkům kvůli mnè, můj Pane. Neodvrátil jsi tvár před hanou a slinou.

Lid: Pane, smiluj se.

Kněz: Šel jsi na porážku jako ovce, na smrt kř̌̌že. Projevil jsi svou nezmérnou péči o mne. Zahubil jsi můj hřich ve svém hrobě. Pozvedl jsi mé prvotiny (bākūratī) k nebi, zjevil jsi mi svůj budoucí př́chod, až sestoupišs soudit živé i mrtvé a dáš každému podle jeho skutků. (Chulágí, s. 262 a $265-266$ )

Odezvy Izajášovy písně o trpícím služebníku se doplňují s aktualizací Kristova smírného utrpení vzhledem ke každému člověku a s vyhlídkou na konečné zúčtování. Celé dílo spásy je shrnuto ve vyznání nad eucharistickými způsobami. 
... proto si, náš Pane, pripomínáme tvé sestoupení na zem, tvou životadárnou smrt, tvé spočiváni $v$ hrobé po tři dny a tvé vzkřišeni z mrtvých, tvé nanebevstoupení a tvé usednutí po pravici Otce, i tvůj druhý príchod, který bude z nebe, hrozný a slavný... (Chulágí, s. 276)

\subsection{Modlitba prì lámání Chleba (qisma)}

Aktualizace zaznívá také $\mathrm{v}$ prosbě kněze před qismou, poté, co zazněly všechny př́mluvné modlitby a připomínky svatých a začíná eucharistická hostina.

Kněz: Ty, který jsi tenkrát požehnal, i nyní požehnej.

Lid: Amen.

Kněz: Ty, který jsi tenkrát posvětil, i nyni posvét.

Lid: Amen.

Kněz: Ty, který jsi tenkrát lámal, i nyni lámej.

Lid: Amen.

Kněz: Ty, který jsi tenkrát dával svým svatým učednikům a apoštolům, i nyní, náš Pane, dej nám a svému lidu, všemohoucí Pane, náš Bože. (Chulágí, s. 305-306)

Při lámání svátostného Chleba se kněz modlí qismu, v níž připomíná, že zde přítomné Kristovo Tělo je nebeský pokrm věřících a jeho svátostná Krev podle oběti na kř́ži očištuje př́tomné z vin.

Požehnaný jsi, Kriste, náš Bože všemohoucí, Spasiteli církve, která je tvá, Slovo vtèlené nepopsatelným vtèlením, tys nám pripravil nebeský chléb - tvé svaté Télo, tajemné a svatosvaté. Smísil jsi pro nás v kalichu čisté víno - tvůj božský, neposkvrnèný bok, z nèhož, se kvưli nám vyřinula voda a krev poté, co jsi odevzdal ducha. Tato voda a krev se stala očistnou lázni (tahar) pro celý svét... Tys nás, ze svého nesmírného milosrdenství, učinil hodnými stát se syny skrze posvátný křest... (Chulágí, s. 308-310)

\subsection{Z dèkovné modlitby knèze}

Po přijímání kněz v děkovné modlitbě znovu připomíná velikonoční tajemství uskutečněné $\mathrm{v}$ eucharistické liturgii k prospěchu každého přijímajícího.

Děkujeme ti, Pane, Kriste, náš Bože, pravé Slovo, čisté podstaty s Otcem, který jsi nás tolik miloval, že ses za nás vydal násilné smrti za naše hríchy. Tvé bičováni a tvé rány nás uzdravily. Daroval jsi nám život ve svém svatém Tẻle a ve své vzácné Krvi, které jsi nám dal k přijímáni. Proto ti dèkujeme, Bože, milující človéka, kterého jsi stvořil... (Chulágí, s. 316) 


\subsection{Ze závèrečné modlitby knèze}

V závěrečné modlitbě za lid znovu vystupuje červená nit dějin spásy, spojující vtělení věčného Boha, spásné utrpení Syna, zmrtvýchvstání, nanebevstoupení k Otci a budoucí soud nad všemi.

Ten, který byl, který je, který príšel a který prijide, který prijial tèlo a stal se človèkem, který byl za nás ukřižován, který dobrovolnè trpèl v tèle, ač jako Bůh nepodléhal utrpení, byl pohřben a uložen do hrobu, vstal z mrtvých třetí den, vstoupil na nebesa a usedl po pravici Otcovy slávy. Ten př́jde soudit živé a mrtvé... Ježíš Kristus, náš Pán... (Chulágí, s. 317-318)

\section{Velikonoční qismy}

Qismy shrnují tajemství velikonoční oběti Kristovy, zpř́tomněné ve svátostných způsobách. Pronáší je kněz při lámání eucharistického Chleba. Texty jsou proměnlivé podle svátků, podle textů Písma odkazují na jednotlivé slavené události a aktualizují je pro prrítomné shromáždění.

\subsection{Qisma o Kvètné nedèli}

... z úst détí a nemluvňat sis připravil chválu. Připrav také naše duše, aby tě chválily... (Chulágí, s. 414)

\subsection{Qisma na Zelený čtvrtek}

... obétováni Izáka bylo predobrazem krveprolití Krista, Božího Syna, ukřžzovaného za spásu svéta. Jako Izák nesl dřevo k celopalu, tak Kristus nesl drevo křžže. Jako se Izák vrátil živý, tak Kristus vstal z mrtvých a ukázal se svým svatým učedníkům. (Chulágí, s. 418-419)

\subsection{Qisma na Bílou sobotu}

... prošel jsi skrz oponu na misto velesvatyně, kam nikdo s lidskou prírozeností (dhū tabī'a bašarīja) nemůže vstoupit. Stal se naším heraldem, veleknèzem navèky podle rádu Melchisedechova. Ty jsi ten, o nèmž prorok Izajáš rekl: Jako ovce byl veden na porážku a jako beránek bez hlesu pred střihači neotevřel svá ústa. Skrz jeho ponižení byl odňat rozsudek... Byl jsi zranèn pro naše hř́chy, zasažen pro naše nepravosti, byl jsi potrestán kvůli našemu pokoji, tvými ranami jsme uzdraveni. Zbloudili jsme jako ovce a ty jsi přišel, náš Pane, a zachránil nás pravdou svého křǐze, daroval jsi nám strom života - své božské Tèlo a svou skutečnou Krev. (Chulágí, s. 421-423) 


\subsection{Qisma o Vzkř́šení}

Pane, všemohouci Bože, Otče našeho Pána, Boha a Spasitele Ježiše Krista, který skrze svůj křiz sestoupil do předpeklí a vyvedl našeho otce Adama a jeho déti do ráje, pohŕbil nás spolu se sebou, svou smrti préemohl moc smrti, tretího dne vstal z mrtvých. zjevil se Marii Magdalské a mluvil s ní takto: Řekni mým bratř́m, aby šli do Galileje a tam mè uvidí. Archandèl sestoupil z nebe, odvalil kámen od vchodu do hrobu a oznámil radostnou zvěst ženám, které nesly vonné masti: Kristus vstal $z$ mrtvých, zničil smrt a obnovil život téch, kdo jsou v hrobè. Kristus dechl do tváre svých svatých učednikư a apoštolů a řekl: Přijmète Ducha svatého. Komu odpustíte hríchy, jsou mu odpuštèny, komu je zadržite, jsou zadrženy. (Chulágí, s. 425-427)

\subsection{Qisma o svátcích Pánè bèhem roku}

... který vstoupil do Jeruzaléma na oslátku jako Král, který ustanovil novou Smlouvu se svými svatými učedniky, dal jim své svaté Télo a svou vzácnou Krev na odpuštèni našich hř́chů, který byl ukřižován, který premohl Satana, byl uložen do hrobu a po třech dnech vstal z mrtvých, kterého uvidèli vyvolení učedníci na Tiberiadském jezeře po jeho zmrtvýchvstání... (Chulágí, s. 434)

\subsection{Syrská qisma}

Vskutku Boží Slovo trpèlo v tèle, byl zabit a pověšen na kř̌ž a jeho duše se oddèlila od tèla, třebaže jeho božstvi se nikdy neoddèlilo od jeho duše a tèla. Byl proboden jeho bok a vyšla krev a voda na odpuštèní celému svétu. Krví a vodou bylo pomazáno jeho télo. Jeho duše se vrátila a znovu se spojila s télem. Syn zemřel na kř́ži za hř́ch, který vládne svétu, a obnovil všechny po levici i po pravici. Krví prolitou na kř̉ži spojil a usmíril nebeštany a pozemśtany, národy a národy, duši a tèlo. Tretího dne vstal z mrtvých... Vèríme, stvrzujeme a vyznáváme, že toto je Tèlo spojené s Krví a toto je Krev spojená s Tẻlem. Ty jsi Kristus, náš Bůh, jehož bok byl kvůli nám proboden kopím na Golgotè $v$ Jeruzalémě, ty jsi Beránek Boži, který snímá hř́ch světa... (Chulágí, s. 435-437) 


\section{Hymny (alhạān)}

Hymny jsou zařazovány do liturgie při různých příležitostech. Zpívají se v koptštině nebo v arabštině, anebo stř́́davě obojím jazykem. Hymnus k přijímání připomíná životadárný chléb Kristova Těla, velikonoční hymny se opět týkají událostí tridua. Jsou nazvány koptskými incipity.

\subsection{Hymnus k prijímání: Pi-wik ente pi-anch (Chléb života)}

Chléb života, který $k$ nám sestoupil z nebe, dal život svétu.

Vidíme tě na oltárí, poživáme tvé Tẻlo a tvou prevzácnou Krev. (Chulágí, s. 449 a 451)

\subsection{Hymnus na Kvètnou nedèli: Osanna (Hosanna)}

Požehnaný, který přicházi ve jménu Páně, ve jménu Páně.

Hosanna, Synu Davidiov, Synu Davidiov.

Hosanna na výsostech, na výsostech.

Hosanna, Králi Izraele, Králi Izraele.

Zpivejme chválu: Alleluja, alleluja, alleluja.

Sláva našemu Bohu, sláva našemu Bohu. (Chulágí, s. 465-467)

\subsection{Hymnus o Vzkríšení: Christos anesti (Kristus vstal)}

Kristus vstal z mrtvých, smrtí premohl smrt.

Tèm, kdo byli v hrobu, daroval véčný život. (Chulágí, s. 468-469)

\subsection{Hymnus o Kristu: Ton sinanarchon Loghon (Odvèké Slovo)}

Chválíme a oslavujeme odvéké Slovo, jsoucí spolu s Otcem a Duchem, zrozeného $z$ Panny $k$ naši spáse, nebot' on svolil a prijal ukřizování, strpèl smrt $v$ tẻle a vzkřisil ty, kdo zemrèli svým slavným vzkř́šením. (Chulágí, s. 469-470)

\section{Závěr}

Kopto-arabské liturgické texty vyjadřují velikonoční tajemství bohatým jazykem Písma a starokřestanské tradice, jak jsme viděli na ukázkách z aktuálně používaných liturgických textů. Anafory svatého Basila a Řehoře vyjadřují události velikonočního tridua především v terminologii oběti - jak Kristovy na křiži, tak eucharistické. Anafora svatého Marka (Cyrila) není v tomto ohledu specifická, proto jsme texty 
neuváděli. Zcela cíleně reflektují Kristovo utrpení, smrt a vzkříšení liturgické hymny a modlitby frakce (qism) k velikonočnímu triduu, a také polední a odpolední kanonické hodinky, které rozjímají o smrti Páně a o pokání lotra po pravici.

Velikonoční tajemství je v uvedených textech formulováno ve shodě s vyznáním víry jako dílo Boží spásy skrze vtělení Božího Syna Ježíše Krista terminologií Písma. Reflektuje se předobrazná exegeze starozákonních textů o Abrahámově obětování syna a Izajášovo proroctví o trpícím služebníku, andělský chvalozpěv trojnásobné Boží svatosti. Z událostí evangelia je $\mathrm{v}$ anafoře zásadním způsobem připomínána Poslední večeře jako ustanovení svátosti Těla k věčnému životu a Krve k očištění od hříchu. Jidášova zrada je interpretována jako pobídka k pokání. Texty zmiňují Kristovo prohlášení o jeho božství před Pilátem, jeho ponížení, políčky, bičování podle proroctví o trpícím služebníku, jeho ukřižování na dřevě, bolest Matky pod křížem, vyznání lotra po pravici a jeho přijetí do věčného království. Liturgie esenciálně vyznává Kristovu smrt v těle, jeho pohřbení a sestup do pekel k vysvobození zemřelých, vzkříšení tř̌etího dne, nanebevstoupení a usednutí po pravici Otce.

Starokřestanské trisagion, které je typickou modlitbou východní liturgie, shrnuje události spásy působivým hymnickým způsobem v jeho koptském i arabském znění: svatý nesmrtelný Bůh se zrodil v těle jako člověk, aby vykoupil lidstvo propadlé hříchu. Zásadní souvislost mezi Kristovým vtělením a vykoupení doplňuje spojitá linie minulého díla a současného účinku ve svátosti eucharistie.

Koptské liturgické texty bohatým a náročným jazykem Písma i tradice spojují poučení o víře s uskutečněním Kristových velikonočních tajemství v posvátném dění, které je účinnou aktualizací událostí spásy v životě účastníků liturgie. 


\section{ABSTRACT \\ MLADA MIKULICOVÁ \\ The Easter mystery in liturgical texts of the arabophone Coptic Church}

Coptic-Arabic liturgical texts express the Easter mysteries in the rich idiom of the Scriptures and ancient Christian tradition, as seen in the Eucharistic Liturgies of St. Basil and St. Gregory, as well as in hymns and prayers of the Sixth and the Ninth Canonical Hours. They concentrate on the sacrifice of Christ on the cross as connected to that of the Holy Mass. The liturgical texts profess, in accordance to the Creed, the Divine economy of salvation in the incarnation of the Son of God and his crucifixion for human sin, his death and descent to the hell as well as ascent to the Father. Prefigured in Isaac and the Suffering Servant, he is seen as establishing the Eucharistic Sacrament on Maundy Thursday to perpetualize the effects of his sacrifice for participants in the Mass. His trial and his suffering before Pontius Pilate is contemplated, along with his crucifixion, his acceptance of the Thief on the Right. The liturgical texts essentially confess Christ's death in the human body, his burial and descent to save the deceased, his resurrection and his ascension to sit with the Father. These points are succintly expressed in the ancient Trisagion. Fundamental is the connection between Christ's incarnation and the redemption as well as between his past work of salvation and its present effect in the Eucharist. Coptic liturgical texts unite catechesis of faith to acting out Christ's Easter mysteries where the salvatory events happen in the life of the participants.

\section{Key words}

Coptic-Arabic liturgical texts, Euchologion, Canonical Hours, St. Basil Liturgy, Easter mystery, incarnation, redemption, Eucharist 